\title{
PENDEKATAN NARRATIVE DALAM PERANCANGAN KONEKTIVITAS RUANG SEMPADAN DI JALAN TAMAN KEMANG
}

\author{
Robert Christopher Pantan ${ }^{1}$, Julia Dewi ${ }^{2}$, Andreas Yanuar ${ }^{3}$ \\ 1,2,3. Jurusan Arsitektur, Fakultas Desain, Universitas Pelita Harapan, \\ Jl. M.H. Thamrin Boulevard 1100 Lippo Village, Tangerang \\ Email: ${ }^{1}$ robertcp50@gmail.com, ${ }^{2}$ julia.dewi@uph.edu, ${ }^{3}$ andreas.wibisono@uph.edu
}

\begin{abstract}
Abstrak
Sebagai area komersial jalan Taman Kemang memiliki aktivitas-aktivitas tertentu berdasarkan fungsinya seperti kegiatan parkir, orang bekerja, aktivitas berjualan (pedagang kaki lima), aktivitas makan maupun bersantai, orang yang sekedar berjalan kaki menuju Lippo Mall Kemang dan kegiatan dari transportasi online untuk mengantar dan menjemput. Akan tetapi, sebagai area komersil jalan Taman Kemang tidak memiliki keseimbangan aktivitas keseharian ruang kota. Hal tersebut dikarenakan aktivitas yang berbeda dipengaruhi oleh waktu dari pagi hingga malam dan hari weekdays maupun weekends. Hal ini disebabkan ruang-ruang sempadan yang terbentuk difungsikan menjadi tempat parkir dan tempat berjualan pedagang kaki lima yang seharusnya dapat difungsikan sebagai ruang publik. Oleh sebab itu, dalam penelitan ini penulis menggunakan pendekatan secara narrative sebagai proses analisis menuju tahap desain melalui tahapan story narrative - narration sebagai solusi pemecahan masalah. Proses analisis yang dilakukan berdasarkan aktivitas-aktivitas di jalan Taman Kemang adalah melalui motif-motif aktivitas masyarakat yang membentuk events dalam waktu tertentu. Sehingga, pada tahap narrative terbentuk konsep cerita yaitu bagaimana menghidupkan kembali ruang sempadan dari narasi keseharian yang terbentuk di jalan Taman Kemang. Kemudian didukung oleh strategi-strategi pada tahap narration melalui 5 strategi landscape narrative dan pembentuk kualitas ruang yaitu terbentuknya identitas aktivitas, identitas ruang dan continuity dari hasil integrasi elemen ruang sempadan.
\end{abstract}

Kata kunci: ruang sempadan, narrative.

\begin{abstract}
Title: Narrative Approach in the Design of Integrated Space Connectivity in Taman Kemang

As a commercial area the Taman Kemang street has certain activities based on its functions such as parking, working, selling (street vendors), eating and relaxing, people who just walk to Lippo Mall Kemang and activities from online transportation to deliver and pick up. However, as a commercial area, the Taman Kemang street does not have the balance of the daily activities as the city space. This is because different activities are defined by time from morning to night and weekdays and weekends. This is because the bordering space that are formed are utilized as parking lots and selling places of the street vendors which it should be utilized more as public spaces. Therefore, in this research, the author uses a narrative approach as an analysis process towards the design stage through the stages of the story-narrative-narration as a problem-solving solution. The process of analysis is based on activities on the Taman Kemang street through the motives of community activities that form events in a certain time. So that in the narrative stage a story concept is formed which is how to revive the bordering space of the daily narrative formed on the Taman Kemang street. Then supported by strategies at the stage of narration through 5 narrative landscape strategies and forming quality space, namely the formation of activity identity, space identity and continuity of the results of the integration of bordering space elements.
\end{abstract}

Keywords: bordering space, narrative. 


\section{Pendahuluan}

Jalan Taman Kemang merupakan area komersil di Jakarta Selatan yang merupakan jalan penghubung dari jalan Antasari dan jalan Kemang Raya (Kem Chick) menuju pintu masuk dan keluar Lippo Mall Kemang. Jalan Taman Kemang memiliki berbagai macam fungsi bangunan seperti perkantoran, tempat industri (apartemen dan hotel), tempat perdagangan dan jasa serta area pemukiman. Hal tersebut membuat jalan Taman Kemang seharusnya memiliki aktivitas-aktivitas yang cukup aktif dan seimbang sebagai ruang kota.

Fenomena pada jalan Taman Kemang memperlihatkan tidak adanya keseimbangan aktivitas yang terjadi di ruang sempadan, baik pagi menjelang malam dan weekdays maupun weekends. Ketidakseimbangan aktivitas yang terjadi karena ruang sempadan di jalan Taman Kemang lebih difungsikan sebagai area lahan parkir. Dominasi fungsi perkantoran diduga menjadi salah satu penyebab ketidakseimbangan aktivitas sepanjang waktu. Hal lain yang diamati pada ruang jalan adalah aktivitas pedagang kaki lima serta transportasi online yang cukup aktif pada waktu-waktu tertentu. Terdapat aktivitas transportasi online yang selalu ada untuk melakukan kegiatan mengantar maupun melakukan penjemputan. Melalui fenomena yang terjadi, kegiatan maupun aktivitas yang terbentuk di jalan Taman Kemang memiliki ceritanya masingmasing melalui orang bekerja hingga orang yang sekedar berjalan kaki, tetapi tidak memiliki keseimbangan aktivitas melalui hari maupun waktu.

Penelitian ini bertujuan untuk menemukan konsep yang dapat digunakan sebagai strategi perancangan melalui pendekatan naratif dari aktivitas keseharian ruang kota. Konsep yang didasarkan pada cerita keseharian diharapkan dapat menghidupkan ruang kota secara lebih seimbang sepanjang periode waktu.

\section{Kajian Teori}

Garis sempadan bangunan (GSB) melalui Undang-Undang No. 28 Tahun 2002 tentang Bangunan Gedung, merupakan pembatas jarak terdekat bangunan dengan tepi jalan, dihitung dari batas terluar air kotor atau tepi jalan sampai batas terluar dari muka bangunan. Batasan-batasan tersebut membentuk sebuah ruang yang disebut sebagai ruang sempadan, diperuntukan sebagai tempat yang bersifat utilitas. Selain sebagai ruang utilitas, ruang sempadan menjamin adanya ruang terbuka hijau yang bersifat publik maupun privasi. Melalui sejarahnya, ruang sempadan merupakan salah satu ruang yang mendukung kehidupan yang lebih sehat dan ruang rekreasi terhadap masyarakat agar masyarakat dapat berinteraksi antara satu dengan lainnya. Ruang sempadan di dalamnya terdapat sebuah jalan yang tidak hanya sebagai koneksi, tetapi bagaimana jalan itu menjadi bagian dari ruang yang berintegrasi dengan bangunan (Burlington City Council, 2019). Oleh sebab itu, ruang sempadan harus mampu menjadi ruang publik yang fungsional, menjadi ruang yang dapat mewadahi masyarakat untuk hidup dan bekerja, ruang publik yang bisa menguatkan suatu komunitas di dalamnya dan membentuk hidup yang lebih sehat (Bain, Gray, and Rodgers, 2012).

\section{Karakteristik Ruang Sempadan}

Karakteristik ruang sempadan terbentuk berdasarkan dari karakter bangunan yang terbentuk (Burlington City Council, 2019).

1. Building height, ketinggian bangunan membentuk integrasi terhadap bangunan dengan jalan di depannya.

2. Building width, berdampak terhadap aktivitas yang ada di depan (frontage) bangunan.

Karakteristik ruang sempadan dapat terbentuk dari dimensi ruang-ruang yang terbentuk secara kualitatif maupun kauntitatif (Ching, 2015). 
1. Base plane, permukaan yang sifatnya continuous.

2. Vertical planes, elemen vertikal yang terbentuk membentuk ruang bisa melalui 1 hingga 2 sisi elemen vertikal berhadapan maupun elemen vertikal yang membentuk sudut L.

3. On space, membuat sebuah ruang dari perbedaan permukaan lahan (lebih tinggi atau lebih rendah).

4. Side space, ruang yang terbentuk di depan maupun di samping dari bangunan vertikal.

5. Between space, ruang yang terbentuk di tengah-tengah elemen bangunan atau elemen vertikal.

6. In space, membentuk sebuah ruang dari batasan-batasan yang ada (enclosure).

Karakteristik yang terbentuk dari ruang sempadan yang menjadi support bagi ruang sosial (Ching, 2015; Mehta, 2009).

1. Seating, fasilitas tempat duduk sebagai ruang publik untuk mendukung terbentuknya sebuah interaksi sosial.

2. Sidewalk width, pedestrian yang difungsikan untuk berjalan bagi masyarakat dengan rasa aman dan nyaman.

3. Articulation width, fungsi dari sebuah fasad sebagai shading bagi ruang yang ada di bawahnya dan menjadi daya tarik sebagai visual terhadap orang yang melihat.

4. Tree cover, canopies, awnings, overhang providing dan shelter, dijadikan sebagai ruang yang dapat dimanfaatkan publik dan menjadi ruang teduh bagi masyarakat yang memanfaatkannya.

5. Street furniture (supporting), tidak hanya tempat duduk, tetapi terdapat street furniture yang mendukung lainnya untuk dimanfaatkan sebagai ruang interaksi masyarakat, terlebih terhadap ruang komersial.

6. Tekstur dan warna, salah satu karakteristik sebuah permukaan untuk memberikan ekspresi dan emosi terhadap visual.
7. Pencahayaan, pemanfaatan cahaya secara alami maupun non alami (buatan), memberikan sebuah kesan tersendiri bagi pengguna.

Sehingga, ruang sempadan memiliki kualitas-kualitas ruang yang bermakna (Ching, 2015).

1. Identitas aktivitas, ruang yang dapat memberikan kesan terhadap pengguna sehingga memiliki identitas aktivitas yang jelas.

2. Identitas ruang, dibagi menjadi 2 aspek yaitu secara orientasi dan teritorial yang terbentuk. Orientasi melalui kepekaan manusia terhadap ruang dan teritorial merupakan batasan-batasan yang membentuk identitas ruang.

3. Continuity, membentuk secara spasial bentuk dari organisasi yang tercipta sehingga menghadirkan pengalaman yang berbeda ketika berada di sepanjang ruang tersebut melalui kedekatan antar ruang maupun adanya penanda yang jelas yang menjadi satu kesatuan.

\section{Elemen Pembentuk Ruang Sempadan}

Melalui karakteristik dari ruang sempadan, dapat dilihat terdapat 5 elemen pembentuk dari ruang sempadan, yaitu pedestrian, bentuk, fasad, furniture dan sensori.

1. Pedestrian, ruang jalan yang terbentuk di atas permukaan bersifat linear yang memampukan orang untuk berjalan maupun untuk berinteraksi sosial (gambar 1).

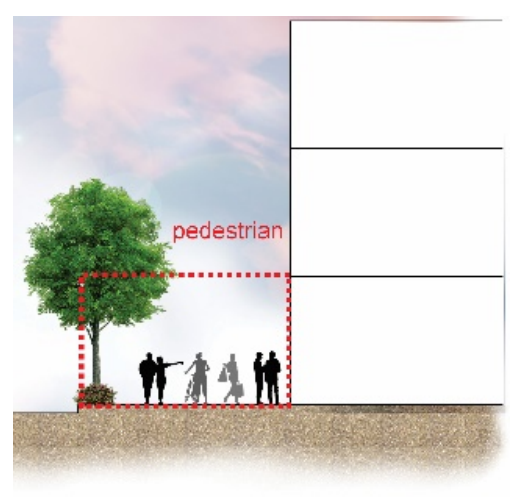

Gambar 1. Diagram pedestrian Sumber: Dokumentasi Robert, 2019 
2. Bentuk, ruang publik yang terbentuk di sisi bangunan atau muka bangunan (side space) dan ruang di antara bangunan (between space) yang bersifat vertikal (gambar 2).

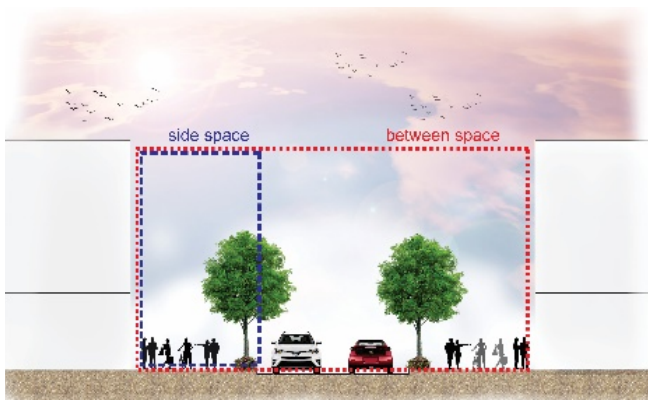

Gambar 2. Diagram bentuk

Sumber: Dokumentasi Robert, 2019

3. Fasad, elemen vertikal dari bangunan yang memiliki fungsi tidak hanya sebagai tempat shading atau berteduh, tetapi juga menjadi dayat tarik (gambar $3)$.

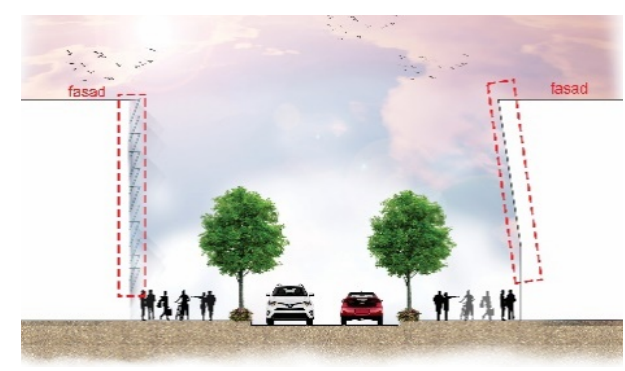

Gambar 3. Diagram fasad Sumber: Dokumentasi Robert, 2019

4. Furniture, sebagai wadah atau fasilitas bagi masyarakat untuk berinteraksi social, sebagai ruang publik yang terbentuk (gambar 4).

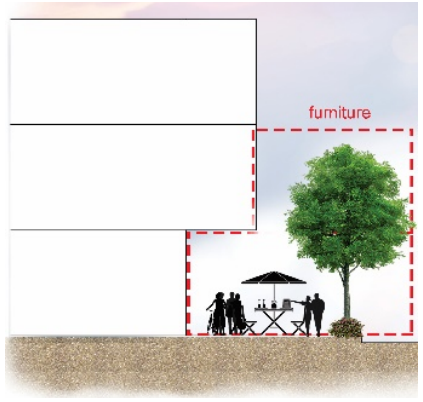

Gambar 4. Diagram furniture Sumber: Dokumentasi Robert, 2019
5. Sensori, memberikan sebuah kesan secara visual, maupun mampu memberikan dampak kenyamanan bagi pengguna (gambar 5).

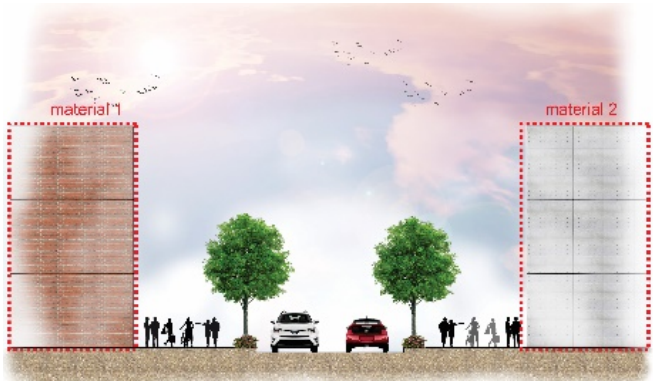

Gambar 5. Diagram sensori

Sumber: Dokumentasi Robert, 2019

\section{Pendekatan secara Narrative}

Pendekatan secara narrative merupakan media untuk menentukan siapa yang menjadi author dan siapa yang menjadi reader (Havik, 2014). Oleh sebab itu, untuk menentukan readernya, dapat dilakukan melalui analisis secara narrative. Analisis secara narrative dapat melalui structuralism yang merupakan salah satu cara untuk membaca dan mengetahui aktivitas-aktivitas yang terbentuk pada suatu ruang maupun waktu melalui story narrative - narration. (Herman and Vervaeck, 2005).

\section{Tahap Story}

Events, tahapan kronologis atau kejadian yang terbentuk melalui motif-motif aktivitas. Actans, merupakan seorang agen-agen yang terlihat atau terlibat dalam suatu peristiwa. Actans memiliki sebuah peran yang menentukan sifat dari karakter setiap agen-agen yang terlibat. Settings, dalam tahapan sebuah cerita terdapat waktu dan tempat (gambar 6).

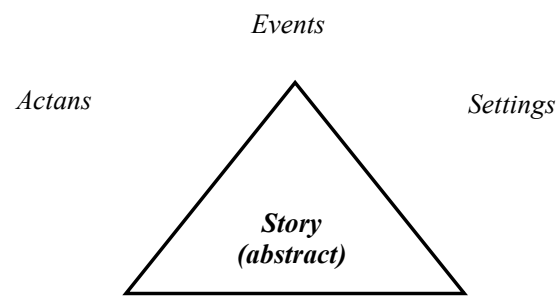

Gambar 6. Integrasi tahap story Sumber: Dokumentasi Robert, 2019 


\section{Tahap Narrative}

Time, merupakan suatu durasi sepanjang jalan cerita. Dapat dihitung berdasarkan panjangnya sebuah alur cerita atau alur sebuah tempat dari titik A menuju titik B. Characterization, bagaimana sebuah agen-agen atau peran yang menampilkan sebuah karakter melalui sifat, atribut dan lain-lain. Focalization, setiap karakter, alur cerita, latar tempat dan informasi yang ada dalam sebuah cerita mampu direspresentatifkan (gambar 7).

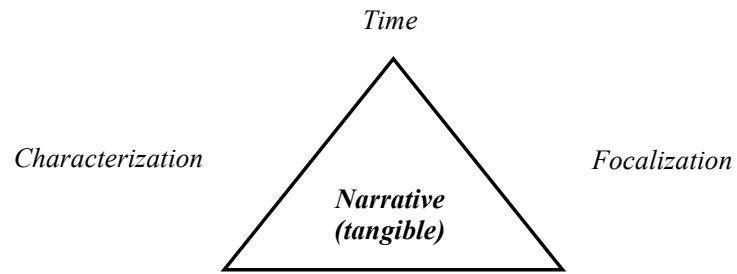

Gambar 7. Integrasi tahap narrative Sumber: Dokumentasi Robert, 2019

\section{Tahap Narration}

Tahap untuk mengimplementasikan dan menyampaikan cerita yang berawal dari abstrak (story) permulaan rangkaian cerita hingga sifatnya yang tangible (narrative) yang merupakan pengenalan secara konkrit karakter, tempat dan cerita yang terbentuk.

Untuk mendukung tahap narration, dapat menggunakan strategy narrative yang merupakan pendekatan antara ruang dengan narrative, melalui 5 strategi yaitu naming, sequencing, gathering, revealing \& concealing dan opening.

\section{Naming}

Merupakan salah satu penerapan pembentukan sebuah identitas ruang publik. Membentuk suatu identitas bisa melalui aktivitas atau suatu penanda seperti signage yang memberikan identitas terhadap suatu area maupun ruang (gambar 8 ).

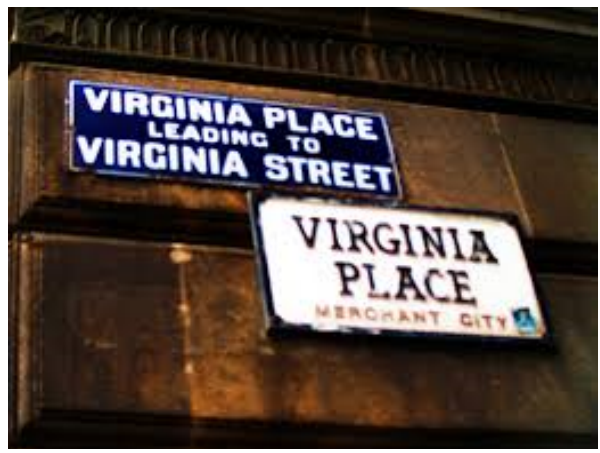

Gambar 8. Penamaan yang diterapkan di Virginia sebagai sejarah Sumber: catswhiskerstours.com Diakses februari, 2019

\section{Sequencing}

Penerapan narrative berdasarkan kronologis sebuah alur cerita yang diterapkan pada ruang publik (gambar 9).

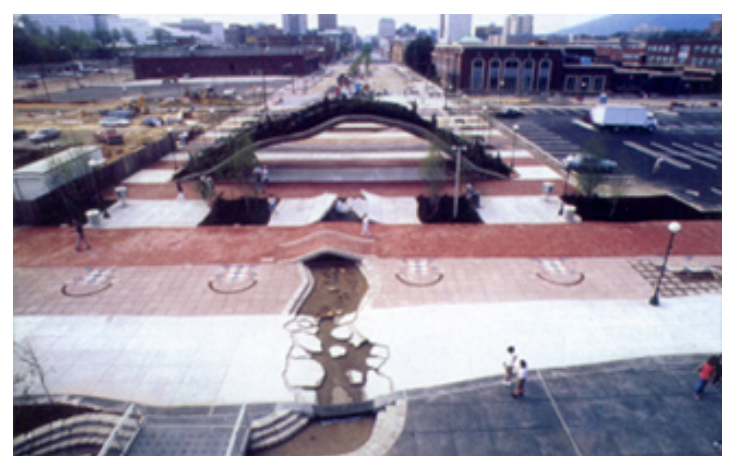

Gambar 9. Penerapan cerita di Ross Landing Sumber: landscapeonline.com Diakses Februari, 2019

\section{Gathering}

Pendekatan melalui ruang publik yang terbuka difungsikan sebagai tempat untuk berkumpul dengan memiliki tujuan tertentu. Sehingga, ruang tersebut menjadi memiliki makna atau cerita yang terkandung di dalamnya (gambar $10)$. 


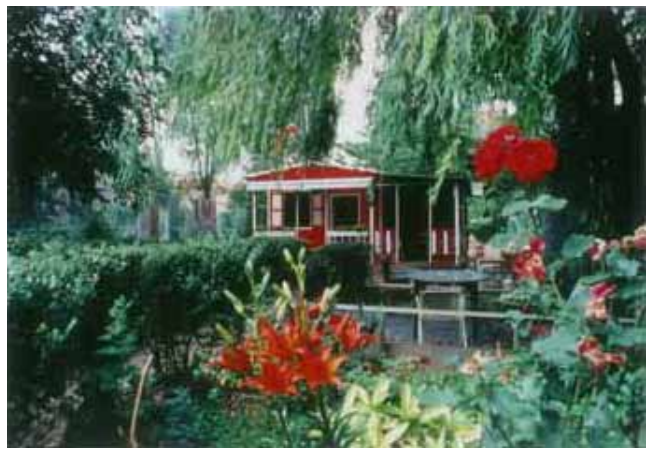

Gambar 10. The Casitas ruang bersama Sumber: painshill.co.uk Diakses Februari, 2019

\section{Revealing \& Concealing}

Pendekatan melalui ruang publik yang bersifat rahasia melalui penempatannya sehingga mampu memberikan suatu pesan tersendiri kepada masyarakat yang memanfaatkannya gambar 11).

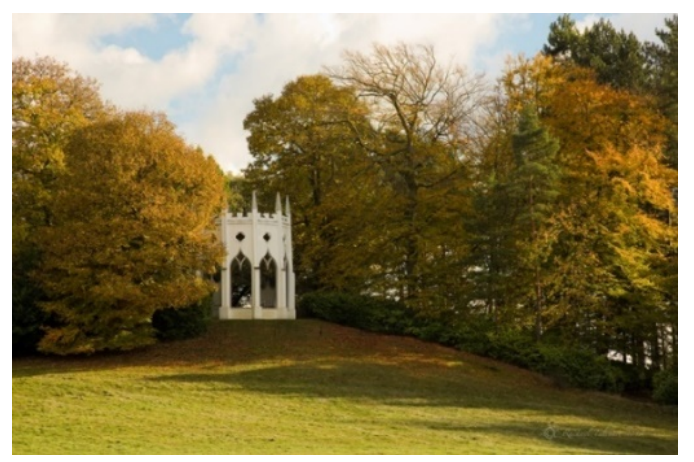

Gambar 11. Painshill Park sebagai ruang publik Sumber: painshill.co.uk Diakses Februari, 2019

\section{Opening}

Ruang publik yang terbuka dan tidak tertutup menjadikan ruang yang dapat dimanfaatkan oleh masyarakat sehingga terbentuk narrative itu sendiri, melalui aktivitas yang terbentuk di ruang tersebut (gambar 12).

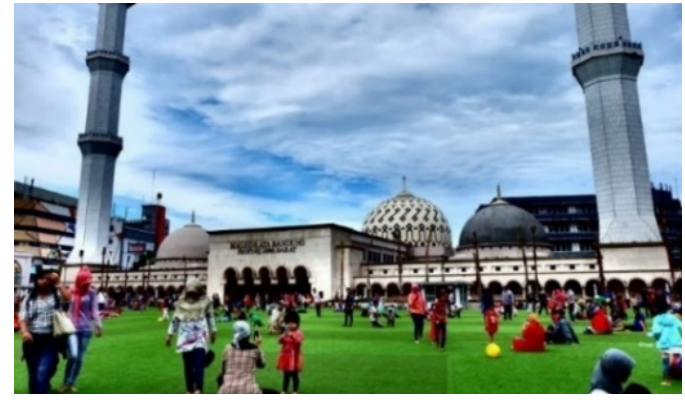

Gambar 12. Alun-alun kota Bandung Sumber: dolandolen.com Diakses Februari, 2019

\section{Metode}

Metode yang digunakan dalam analisis ini dilakukan secara kualitatif dari ruang sempadan yang terbentuk di sepanjang jalan Taman Kemang sebagai area studi dengan melihat fungsi-fungsi dari setiap bangunan yang terbentuk di sepanjang jalan Taman Kemang (gambar 13).

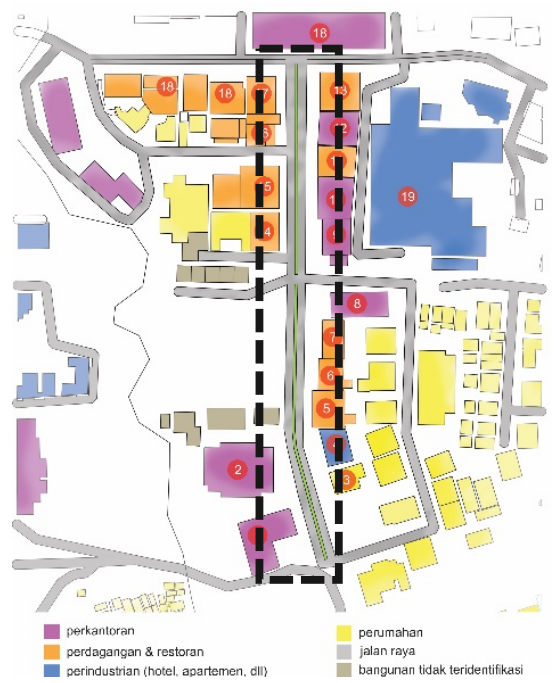

Gambar 13. Area analisis jalan Taman Kemang Sumber: Dokumentasi Robert, 2019

Kualitas yang terbentuk dianalisis melalui elemen pembentuk karakteristik ruang sempadan yaitu pedestrian, bentuk, fasad, furniture dan sensori. Setelah tahapan analisis secara kualitatif terhadap jalan Taman Kemang, tahapan selanjtunya melalui pendekatan secara narrative melalui story - narrative - narration untuk mengetahui aktivitas-aktivitas yang terbentuk di sepanjang jalan Taman 
Kemang hingga menemukan solusi permasalahan melalui konsep perancangan.

Pada tahap story merupakan analisis untuk mengetahui aktivitas-aktivitas yang terbentuk di sepanjang jalan Taman Kemang. Tahap berikutnya yaitu narrative merupakan tahapan untuk menentukan konsep perancangan terhadap respon dari hasil analisis aktivitas yang terbentuk di jalan Taman Kemang. Pada tahap akhir narration, merupakan salah satu cara untuk mengimplementasikan

konsep perancangan melalui 5 strategy narrative yaitu naming, sequencing, revealing \& concealing, gathering dan opening.

Melalui hasil analisis ini, diharapkan dapat menjadi salah satu potensi metode baru yang bertujuan untuk mengindentifikasi aktivitas yang terjadi di sepanjang jalan Taman Kemang dan mampu menyelesaikan permasalahan yang terjadi melalui analisis aktivitas-aktivitas masyarakat tersebut di ruang-ruang sempadan. Sehingga, penelitian ini diharapkan dapat dikembangkan dan dijadikan metode baru dalam proses analisis (gambar 14).

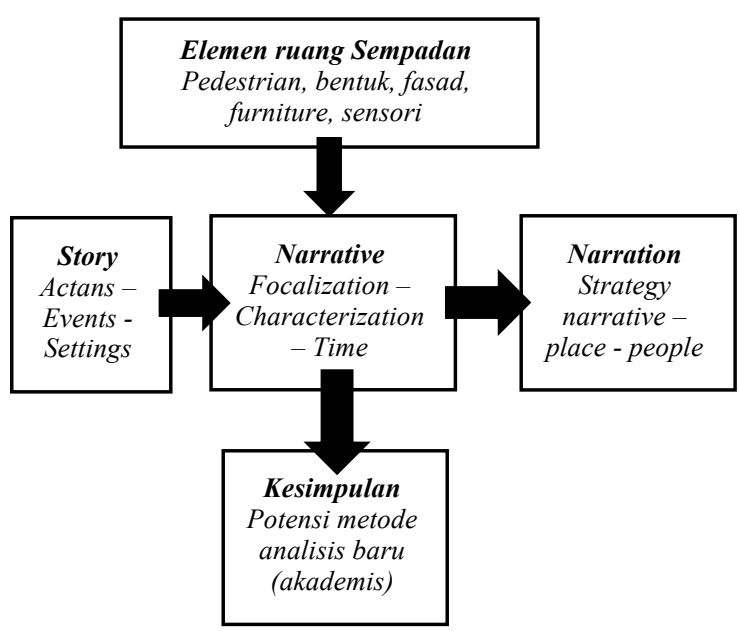

Gambar 14. Kerangka studi penelitan Sumber: Dokumentasi Robert, 2019

\section{Hasil dan Pembahasan}

\section{Kualitas Ruang Sempadan Jalan Taman Kemang}

Dari elemen pembentuk ruang sempadan dapat dilihat kualitas yang terjadi di sepanjang jalan Taman Kemang.

1. Pedestrian

Terdapat kualitas pedestrian yang baik maupun kualitas pedestrian yang tidak baik. Hal ini dikarenakan mayoritas ruang sempadan difungsikan sebagai tempat lahan parkir (gambar 15).
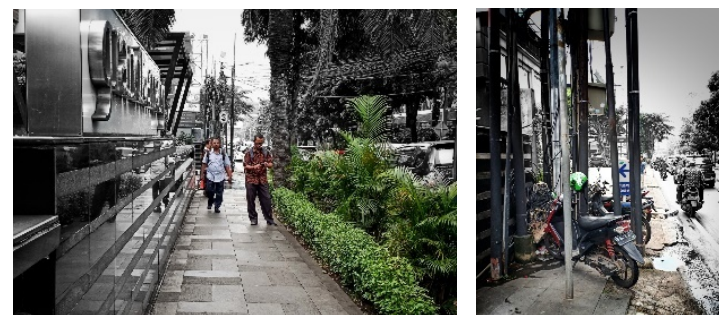

Gambar 15. Kualitas pedestrian yang baik dan tidak baik

Sumber: Dokumentasi Robert, 2019

2. Bentuk

Ruang sempadan yang terbentuk di depan atau samping bangunan dan di antara bangunan difungsikan sebagai area parkir dan pedagang kaki lima (gambar 16).
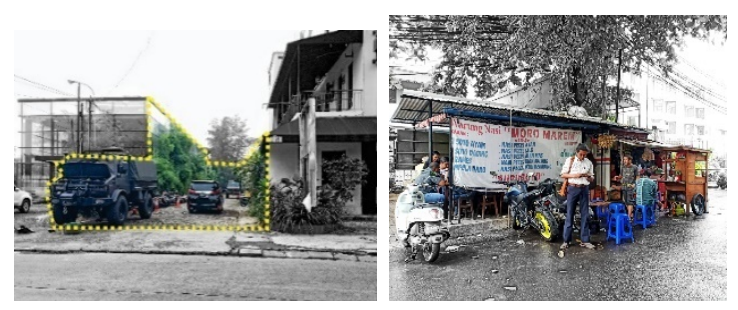

Gambar 16. Ruang yang terbentuk di antara bangunan dan di depan bangunan Sumber: Dokumentasi Robert, 2019

3. Fasad

Fasad dari setiap bangunan di sepanjang jalan Taman Kemang memiliki karakteristik yang masing-masing sesuai dengan fungsinya sebagai gedung kantor yang dominan dengan mirror glass dan bangunan restoran atau café memainkan 
material beton, kayu dan batu alam (gambar 17).
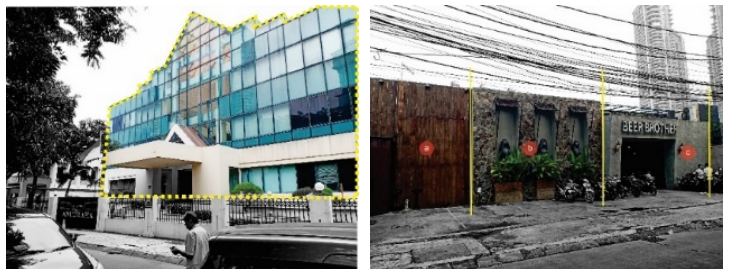

Gambar 17. Gedung kantor dengan fasad mirror glass dan restoran dengan material kayu, batu alam dan beton

Sumber: Dokumentasi Robert, 2019

\section{Furniture}

Sepanjang jalan Taman Kemang sedikit memiliki furniture, terdapat satu halte dan kanopi dari tiap bangunan. Akan tetapi, tidak terdapat fasilitas tempat orang duduk, sehingga masyarakat sekitar lebih memanfaatkan kursi dari pedagang kaki lima untuk duduk dan beristirahat (gambar 18).
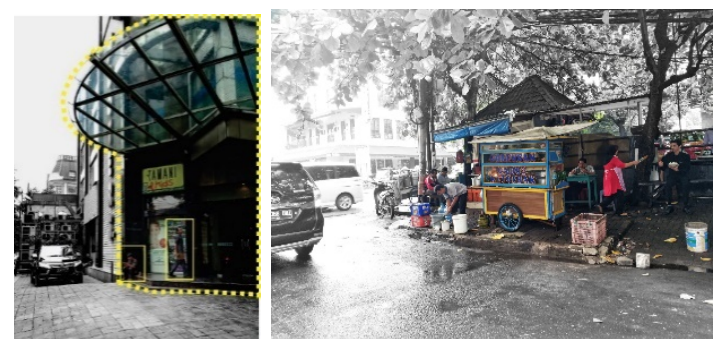

Gambar 18. Kanopi bangunan dan kursi pedagang kaki lima sebagai tempat duduk Sumber: Dokumentasi Robert, 2019

\section{Sensori}

Ruang sempadan dapat menghadirkan rasa nyaman melalui pedestrian dengan kualitas yang baik, namun sebaliknya melalui pedestrian dengan kualitas yang kurang baik membuat orang yang berjalan tidak memiliki rasa nyaman. Selain itu, dari pencahayaan terdapat kualitas yang baik dan tidak baik, sehingga terdapat ruang-ruang sempadan yang gelap dan sulit untuk dilewati (gambar 19).

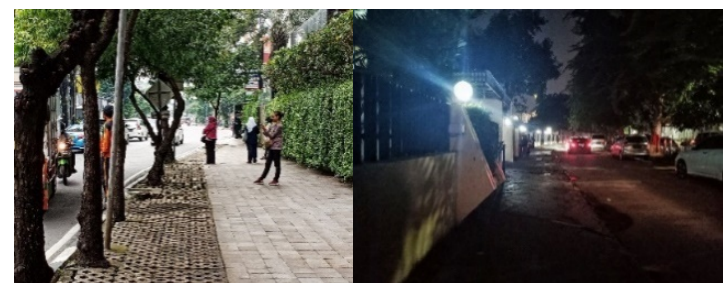

Gambar 19. Pedestrian yang baik dengan pencahayaan yang kurang baik Sumber: Dokumentasi Robert, 2019

\section{Analisis Pendekatan Narrative di Jalan Taman Kemang}

Analisis pendekatan narrative untuk melihat aktivitas-aktivitas yang terbentuk di sepanjang jalan Taman Kemang melalui tahapan story. Pada tahap story dapat melihat actans apa yang terjadi melalui motif-motif kegiatan yang terbentuk di sepanjang jalan Taman Kemang hingga menghasilkan events tertentu. Settings yang terletak di sepanjang jalan Taman Kemang dianalisis berdasarkan waktu pagi hingga malam dan weekdays maupun weekends (tabel 1).

Tabel 1. Hasil analisis actans dan events di jalan Taman Kemang

\begin{tabular}{|c|c|c|c|}
\hline Waktu & Weekdays & Weekends & Kesimpulan \\
\hline $\begin{array}{c}07.00- \\
11.00\end{array}$ & $\begin{array}{l}\text { - } \quad \text { Parkir untuk bekerja (orang } \\
\text { kantoran). } \\
\text { - PKL bersiap untuk } \\
\text { berjualan. } \\
\text { - Transportasi online } \\
\text { mengantar penumpang } \\
\text { menuju pintu masuk dan } \\
\text { keluar Lippo Mall Kemang. }\end{array}$ & $\begin{array}{l}\text { Parkir untuk berakhir } \\
\text { pekan di Lippo Mall } \\
\text { Kemang. } \\
\text { PKL bersiap untuk } \\
\text { berjualan. } \\
\text { Transportasi online } \\
\text { mengantar penumpang } \\
\text { menuju pintu masuk dan } \\
\text { keluar Lippo Mall } \\
\text { Kemang. }\end{array}$ & $\begin{array}{l}\text { Hari weekdays dan weekends } \\
\text { memiliki events dan motif } \\
\text { yang sama yaitu terdapatnya } \\
\text { transportasi } \\
\text { beraktivitas } \\
\text { penumpang dan PKL bersiap } \\
\text { untuk berjualan. }\end{array}$ \\
\hline
\end{tabular}




\begin{tabular}{|c|c|c|c|}
\hline Waktu & Weekdays & Weekends & Kesimpulan \\
\hline $\begin{array}{c}11.00- \\
13.00\end{array}$ & 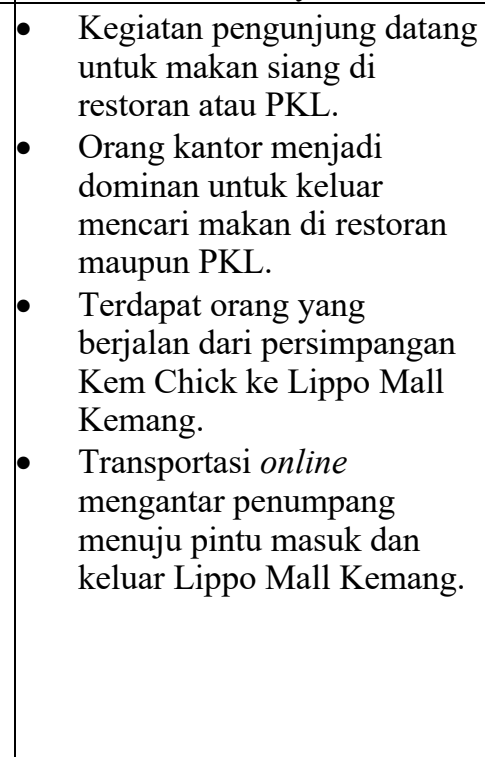 & $\begin{array}{l}\text { Kegiatan pengunjung } \\
\text { datang untuk makan } \\
\text { siang di restoran atau } \\
\text { PKL. } \\
\text { Terdapat orang yang } \\
\text { berjalan dari } \\
\text { persimpangan Kem } \\
\text { Chick ke Lippo Mall } \\
\text { Kemang. } \\
\text { Transportasi online } \\
\text { mengantar penumpang } \\
\text { menuju pintu masuk dan } \\
\text { keluar Lippo Mall } \\
\text { Kemang. } \\
\text { Terdapat orang yang } \\
\text { berjalan dari } \\
\text { persimpangan Kem } \\
\text { Chick ke Lippo Mall } \\
\text { Kemang. }\end{array}$ & $\begin{array}{l}\text { Kegiatan makan menjadi } \\
\text { dominan pada hari weekdays } \\
\text { maupun weekends. Selama } \\
\text { kegiatan berlangung, } \\
\text { transportasi online tetap ada } \\
\text { untuk mengantar penumpang. }\end{array}$ \\
\hline $\begin{array}{c}13.00- \\
17.00\end{array}$ & $\begin{array}{l}\text { Kegiatan pengunjung (sopir) } \\
\text { datang untuk menjemput } \\
\text { anak yang bersekolah di } \\
\text { SPH. } \\
\text { Sebagian orang setelah } \\
\text { makan bekerja dan ada } \\
\text { beberapa orang yang } \\
\text { beristirahat, duduk atau } \\
\text { berinteraksi dalam ruang } \\
\text { publik yang informal di } \\
\text { tempat-tempat tertentu. } \\
\text { Pengunjung yang datang } \\
\text { juga memanfaatkan ruang } \\
\text { publik informal tersebut. } \\
\text { Terdapat orang yang } \\
\text { berjalan dari persimpangan } \\
\text { Kem Chick ke Lippo Mall } \\
\text { Kemang. } \\
\text { Transportasi online } \\
\text { mengantar penumpang } \\
\text { menuju pintu masuk dan } \\
\text { keluar Lippo Mall Kemang. }\end{array}$ & $\begin{array}{l}\text { - Pengunjung yang datang } \\
\text { juga memanfaatkan } \\
\text { ruang publik informal } \\
\text { tersebut. } \\
\text { Kegiatan pengunjung } \\
\text { (sopir) datang untuk } \\
\text { menjemput acara } \\
\text { keluarga yang berada di } \\
\text { Lippo Mall Kemang. } \\
\text { Terdapat orang yang } \\
\text { berjalan dari } \\
\text { persimpangan Kem } \\
\text { Chick ke Lippo Mall } \\
\text { Kemang. } \\
\text { Transportasi online } \\
\text { mengantar penumpang } \\
\text { menuju pintu masuk dan } \\
\text { keluar Lippo Mall } \\
\text { Kemang. }\end{array}$ & $\begin{array}{l}\text { Terdapat ruang publik yang } \\
\text { informal dimanfaatkan orang } \\
\text { kantor maupun pengunjung } \\
\text { untuk beristirahat maupun } \\
\text { berinteraksi antara satu dengan } \\
\text { yang lain. }\end{array}$ \\
\hline $\begin{array}{c}17.00- \\
19.00\end{array}$ & $\begin{array}{l}\text { Orang-orang kantor setelah } \\
\text { bekerja, terdapat beberapa } \\
\text { yang memutuskan untuk } \\
\text { langsung pergi ada yang } \\
\text { memutuskan untuk makan } \\
\text { malam. } \\
\text { Kegiatan pengunjung datang } \\
\text { untuk makan malam di } \\
\text { restoran atau PKL. } \\
\text { Terdapat orang yang } \\
\text { berjalan dari persimpangan } \\
\text { Kem Chick ke Lippo Mall } \\
\text { Kemang. } \\
\text { Transportasi online } \\
\text { mengantar dan menjemput }\end{array}$ & $\begin{array}{l}\text { Kegiatan pengunjung } \\
\text { datang untuk makan } \\
\text { malam di restoran atau } \\
\text { PKL. } \\
\text { Terdapat orang yang } \\
\text { berjalan dari } \\
\text { persimpangan Kem } \\
\text { Chick ke Lippo Mall } \\
\text { Kemang. } \\
\text { Transportasi online } \\
\text { mengantar dan } \\
\text { menjemput penumpang } \\
\text { menuju pintu masuk dan } \\
\text { keluar Lippo Mall } \\
\text { Kemang. }\end{array}$ & $\begin{array}{l}\text { Kegiatan orang pulang kantor } \\
\text { dominan pada hari weekdays } \\
\text { dan pada hari weekends orang } \\
\text { datang sebagai pengunjung } \\
\text { untuk makan maupun pergi ke } \\
\text { Lippo Mall Kemang. Kegiatan } \\
\text { transportasi online masih tetap } \\
\text { ada dalam kegiatan mengantar } \\
\text { dan menjemput penumpang. }\end{array}$ \\
\hline
\end{tabular}




\begin{tabular}{|c|c|c|c|}
\hline Waktu & Weekdays & Weekends & Kesimpulan \\
\hline & $\begin{array}{l}\text { penumpang menuju pintu } \\
\text { masuk dan keluar Lippo } \\
\text { Mall Kemang. }\end{array}$ & & \\
\hline $\begin{array}{l}19.00- \\
23.30\end{array}$ & $\begin{array}{l}\text { Kegiatan pengunjung datang } \\
\text { untuk makan malam di } \\
\text { restoran. } \\
\text { Terdapat orang yang } \\
\text { berjalan dari persimpangan } \\
\text { Kem Chick ke Lippo Mall } \\
\text { Kemang. } \\
\text { Pedagang PKL mulai pergi, } \\
\text { setelah berjualan dari jam } \\
\text { 21.00 hingga pukul } 24.00 . \\
\text { Transportasi online } \\
\text { mengantar dan menjemput } \\
\text { penumpang menuju pintu } \\
\text { masuk dan keluar Lippo } \\
\text { Mall Kemang. }\end{array}$ & $\begin{array}{l}\text { Kegiatan pengunjung } \\
\text { datang untuk makan } \\
\text { malam di restoran. } \\
\text { Terdapat orang yang } \\
\text { berjalan dari } \\
\text { persimpangan Kem } \\
\text { Chick ke Lippo Mall } \\
\text { Kemang. } \\
\text { Pedagang PKL mulai } \\
\text { pergi, setelah berjualan } \\
\text { dari jam } 21.00 \text { hingga } \\
\text { pukul } 24.00 \text {. } \\
\text { Transportasi online } \\
\text { mengantar dan } \\
\text { menjemput penumpang } \\
\text { menuju pintu masuk dan } \\
\text { keluar Lippo Mall } \\
\text { Kemang. }\end{array}$ & $\begin{array}{l}\text { Kegiatan orang pengunjung } \\
\text { dominan pada hari weekdays } \\
\text { dan pada hari weekends orang } \\
\text { datang sebagai pengunjung } \\
\text { untuk makan maupun pergi ke } \\
\text { Lippo Mall Kemang. Kegiatan } \\
\text { transportasi online masih tetap } \\
\text { ada dalam kegiatan mengantar } \\
\text { dan menjemput penumpang. }\end{array}$ \\
\hline
\end{tabular}

Sumber : Dokumentasi Robert, 2019

Melalui hasil analisis berdasarkan waktu, maka dapat dilihat bahwa terjadi ketidak keseimbangan aktivitas. Hal tersebut dikarenakan pada hari weekdays didominasi pekerjaan orang kantor hingga sore, tetapi ketika malam menjadi tidak hidup karena orang kantor yang pulang. Pengunjung yang datang ke jalan Taman Kemang lebih memilih untuk masuk ke dalam bangunan (restoran) dibandingkan beraktivitas di sepanjang ruang sempadan karena ruang sempadan lebih difungsikan sebagai lahan parkir dan tidak adanya aktivitas tertentu. (gambar 20).
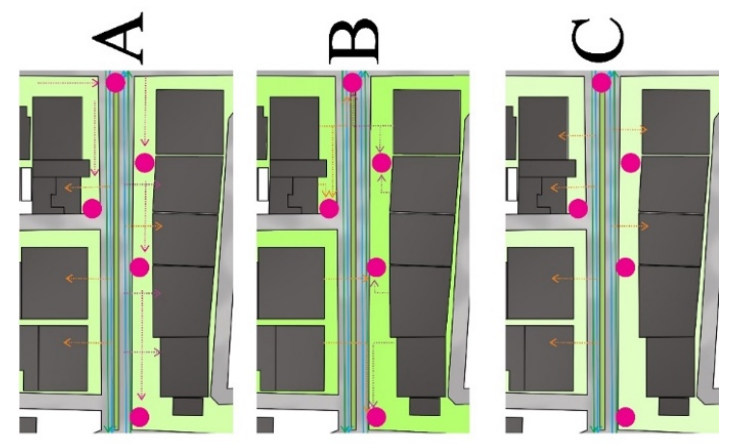

Gambar 20. Diagram aktivitas pagi - malam Sumber: Dokumentasi Robert, 2019
Selain itu, hasil analisis mendapatkan 7 aktivitas utama yaitu kegiatan orang bekerja, makan, beristirahat, berjualan, berjalan kaki, parkir dan mengantar \& menjemput yang menjadikan narasi keseharian di jalan Taman Kemang.

\section{Konsep Solusi dari Hasil Analisis Berdasarkan Pendekatan Narrative}

Setelah menemukan hasil analisis tahap story, proses analisis berikutnya berada pada tahap narrative dan narration. Tahap dimana menghasilkan konsep sebagai solusi dari hasil analisis yang terjadi di jalan Taman Kemang. Secara konsep besar ditekankan kepada menjawab kebutuhan 7 narasi keseharian yang terbentuk di jalan Taman Kemang. Melalui strategy narrative, penekanan konsep gathering yang menempatkan ruang-ruang gathering untuk berkumpul yang menjadi wadah atau fasilitas bagi narasi keseharian. Selain mewadahi kegiatan narasi keseharian melalui ruang gathering, untuk meningkatkan aktivitas yang terbentuk di jalan Taman Kemang, dilakukan intervensi kegiatan-kegiatan baru seperti live movie 
dan art \& performance sebagai daya tarik bagi masyarakat sekitar. Live movie dan art performance merupakan aktivitas entertainment malam hari bagian di dalam gedung yang berupaya ditarik keluar sehingga menjadi bagian aktivitas yang lebih inklusif pada ruang jalan.

Selain intervensi kegiatan baru yang terkait dengan entertainment, intervensi juga dilakukan melalui graphic education seperti mural dan hologram, yang difungsikan sebagai tempat-tempat berfoto, tetapi dimanfaatkan sebagai edukasi bagi masyarakat sekitar. Serta didukung melalui permainan warna cahaya sebagai bentuk daya tarik melalui kontras warna yang diberikan. Hingga pada tujuannya, melalui ketidakseimbangan aktivitas yang terjadi, bagaimana konsep gathering bisa menjadi solusi menghidupkan ruang sempadan di jalan Taman Kemang melalui ruang-ruang gathering dan intervensi yang dilakukan di sepanjang jalan Taman Kemang. (gambar 21).

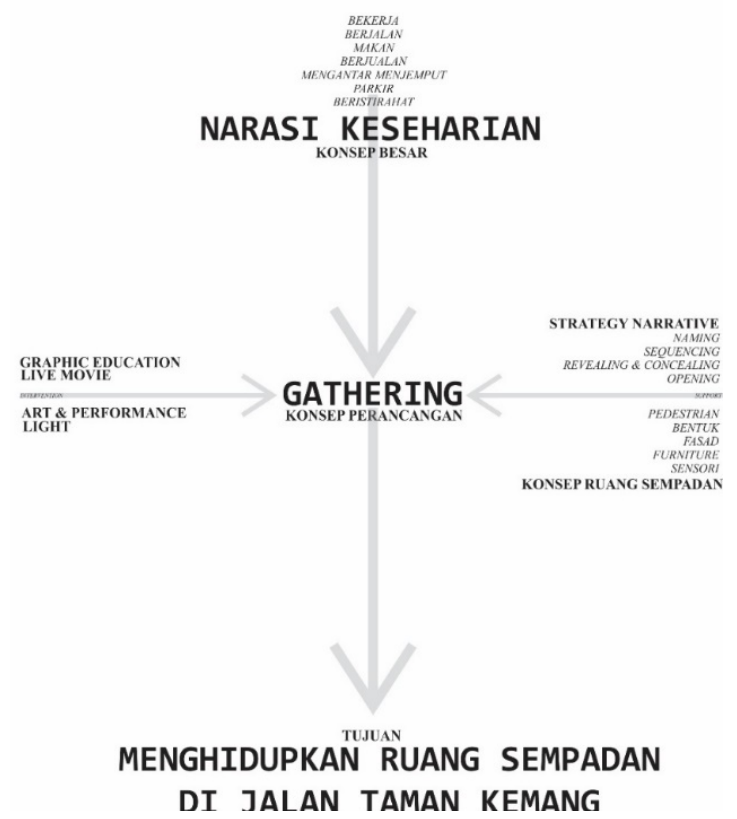

Gambar 21. Kerangka konsep gathering

Sumber: Dokumentasi Robert, 2019

\section{Konsep Gathering}

Menerapkan titik-titik ruang gathering di sepanjang jalan Taman Kemang yang dimana terdapat 7 titik ruang gathering yang dibagi menjadi 2 fungsi utama yaitu gathering tempat makan (merah) dan gathering tempat beristirahat maupun berinteraksi satu dengan yang lainnya (ungu).

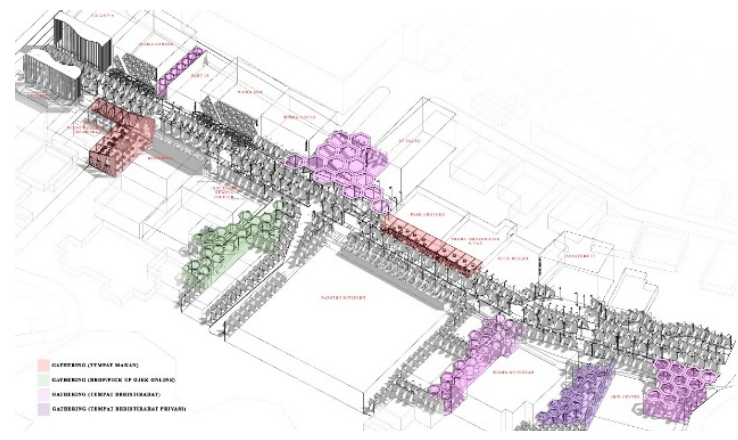

Gambar 22. Titik ruang gathering

Sumber: Dokumentasi Robert, 2019

Terdapat 2 tempat fungsi gathering tempat makan yang berada di antara bangunan Monopoli dan Tanamera. Selanjutnya terdapat di depan bangunan Beer Brother dan Franks Smokehouse \& Bar yang merupakan fungsi bangunan restoran dan cafe (gambar 22 dan 23).

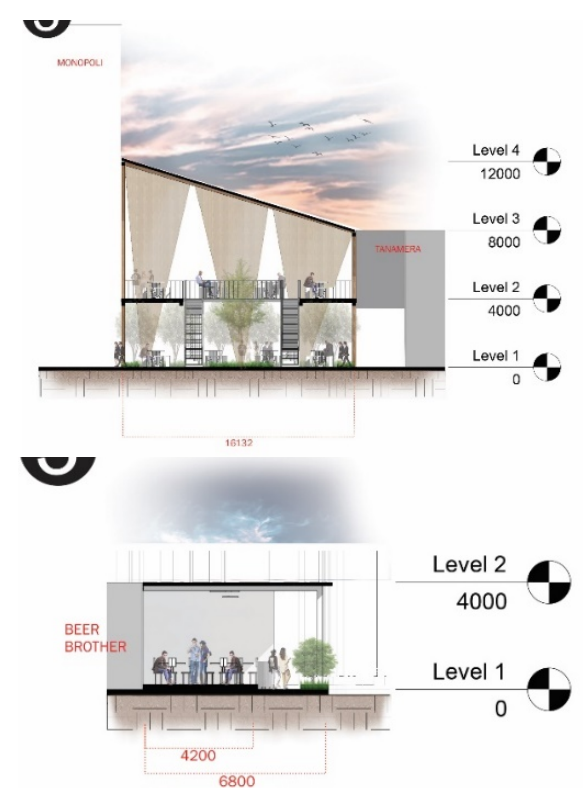

Gambar 23. Potongan gathering tempat makan Sumber: Dokumentasi Robert, 2019

Ruang gathering tempat makan didukung melalui penerapan naming (signage) 
sebagai penjelas identitas ruang maupun aktivitas (gambar 24).
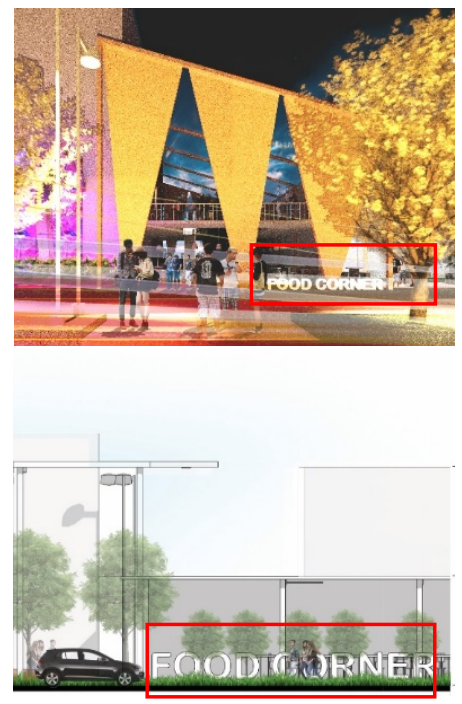

Gambar 24. Penerapan signage Sumber: Dokumentasi Robert, 2019

Selanjutnya terdapat 5 tempat gathering untuk orang beristirahat maupun berinteraksi antara satu dengan yang lain. Terdapat 4 tempat yang bersifat publik, yaitu ruang yang terbentuk di antara bangunan Wisma Sumeru dengan Parc 19 dan di antara bangunan Foodism dengan Transportation Online Hub yang fungsinya sebagai tempat mengantar dan menjemput dari driver transportation online (gambar 22 dan 25).

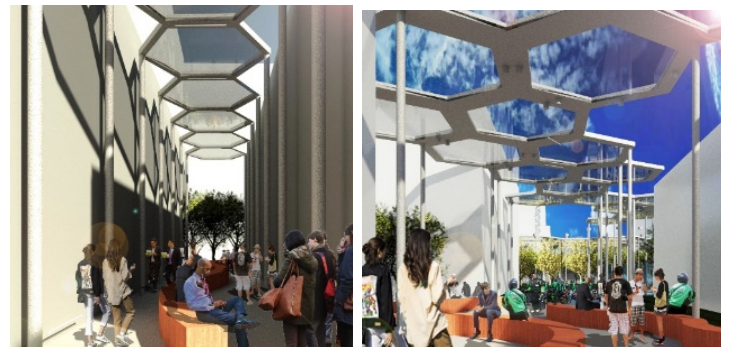

Gambar 25. Gathering tempat beristirahat Sumber: Dokumentasi Robert, 2019

Selanjutnya terdapat di antara bangunan Wisma Agung dengan PT. Pacto dan Bangunan di depan Inti Center (gambar 22 dan 26).
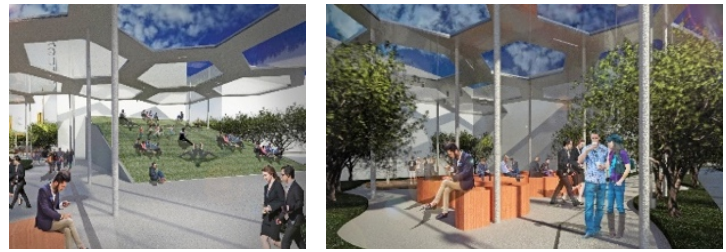

Gambar 26. Gathering tempat beristirahat Sumber: Dokumentasi Robert, 2019

Terakhir, ruang terbentuk di antara bangunan Wisma Anugerah dengan bangunan tidak terpakai dan di antara bangunan Wisma Agung dan Inti Center yang dikarenakan ruang dikhususkan untuk orang-orang kantor. Terdapat intervensi fasad yang difungsikan sebagai tempat untuk duduk dan beristirahat (gambar 22 dan 27).
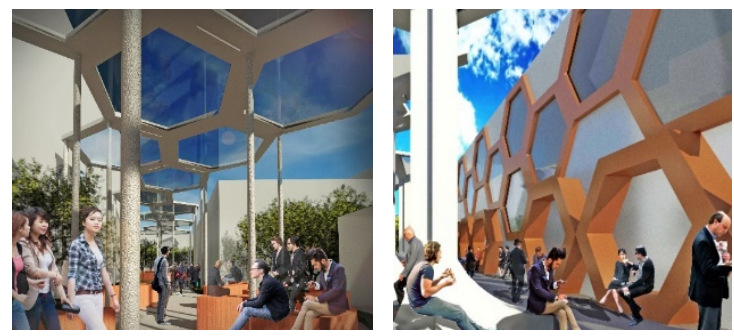

\section{Gambar 27. Gathering tempat beristirahat} Sumber: Dokumentasi Robert, 2019

Ruang-ruang gathering yang terbentuk menerapkan supporting furniture berupa tempat duduk dan kanopi sebagai shelter bagi masyarakat sekitar. Penerapan kanopi yang berbentuk poligon memiliki filosofi dengan makna tidak hanya sifat modular yang mudah untuk dipasang, tetapi menjadi salah satu sifat modular yang mengikat dengan harapan ruang gathering yang terbentuk menjadi pengikat bagi masyarakat sekitar, sehingga ruang sempadan akan menjadi hidup (gambar 28). 


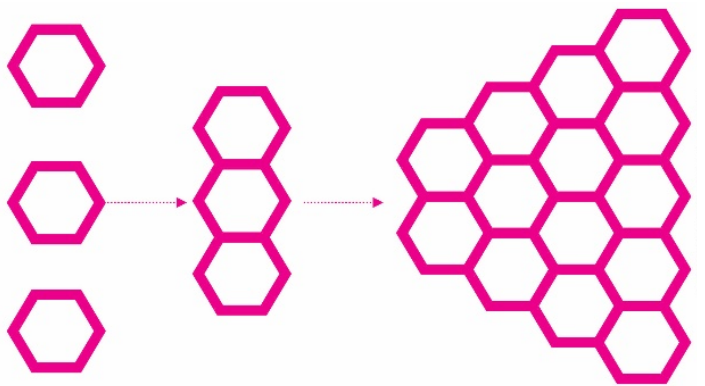

Gambar 28. Filosofi bentuk poligon Sumber: Dokumentasi Robert, 2019

\section{Intervensi di Ruang Sempadan}

Setelah penerapan ruang gathering, untuk menghidupkan ruang sempadan di sepanjang jalan Taman Kemang dilakukan dengan melakukan intervensi kegiatan baru yaitu live music yang terletak di ruang gathering antara bangunan Wisma Agung dengan PT. Pacto. Intervensi yang dilakukan lainnya dengan memanfaatkan fasad dari bangunan sebagai screen untuk menonton dan tempat duduk yang landai dengan permukaan rumput sebagai tempat duduk (gambar 29).

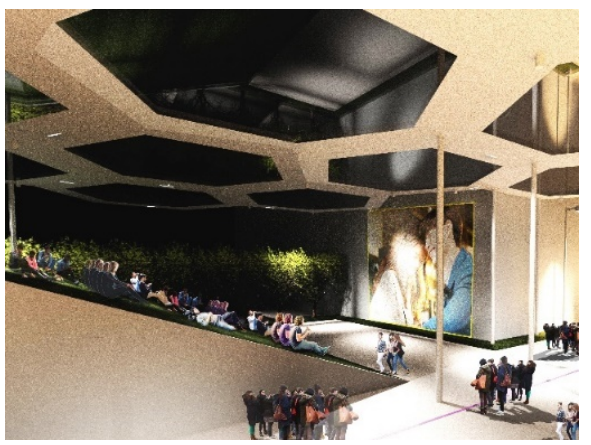

Gambar 29. Intervensi live movie Sumber: Dokumentasi Robert, 2019

Selanjutnya kegiatan art \& performance berada di antara bangunan Wisma Anugerah dengan gedung yang tidak terpakai dan di depan Inti Center. Selain intervensi kegiatan, intervensi yang dilakukan dengan pencahayaan yang kontras sehingga dapat mengundang masyarakat sekitar (gambar 30).
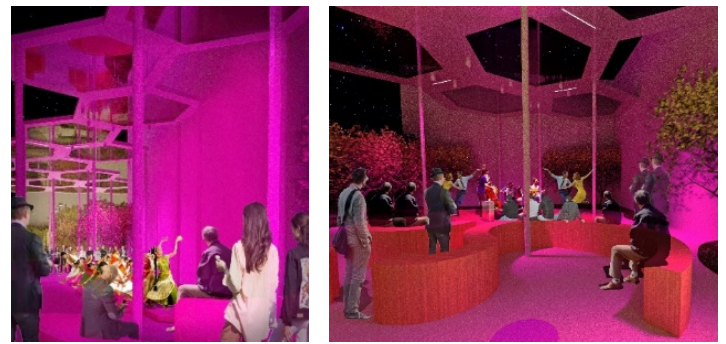

Gambar 30. Intervensi art \& performance Sumber: Dokumentasi Robert, 2019

Intervensi lainnya yang dilakukan dengan menerapakan graphic education melalui mural yang diterapkan di titik-titik ruang sempadan. Pertama, terletak di ruang gathering di antara Wisma Sumeru dan Parc 19. Intervensi mural yang memberikan informasi mengenai kegiatan-kegiatan yang terjadi di sepanjang jalan Taman Kemang (gambar 22 dan 31).

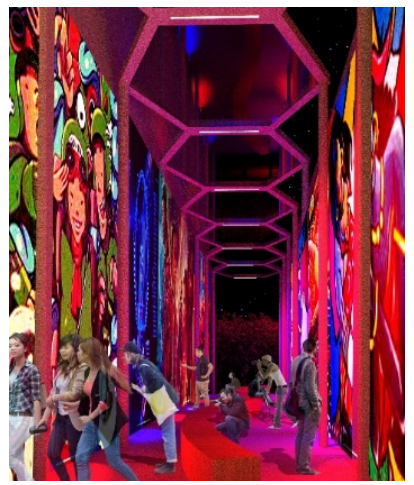

Gambar 31. Intervensi art \& performance Sumber: Dokumentasi Robert, 2019

Terdapat intervensi graphic education di depan bangunan dari Monopoli dan gedung parkir. Didukung melalui penerapan tunnel sebagai sequencing menuju tujuan yaitu live movie dan art \& performance setelah melihat intervensi mural (gambar 32).
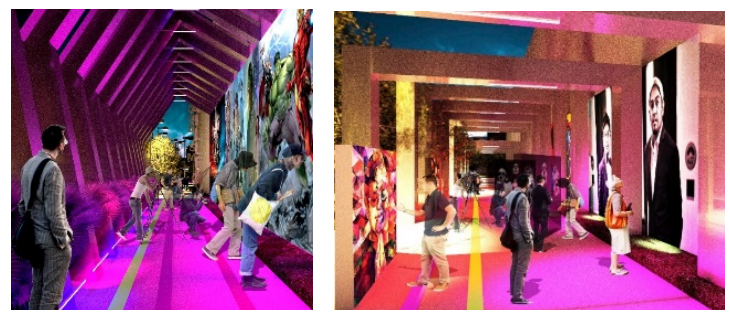

Gambar 32. Intervensi graphic design Sumber: Dokumentasi Robert, 2019 
Selanjutnya terdapat intervensi fasad terhadap bangunan perkantoran, yaitu bangunan Wisma Sumeru dan Wisma Naf, fasad yang dapat difungsikan sebagai tempat duduk oleh masyarakat sekitar. Intervensi yang dilakukan dengan menempatkan hologram di tengah sirkulasi pedestrian sebagai daya tarik. Pada siang hari menjadi air yang mengalir dan malam hari dengan memberikan informasiinformasi yang terjadi di sepanjang jalan Taman Kemang maupun informasi berupa berita. Hal tersebut merupakan salah satu penekanan dari intervensi graphic education (gambar 33).
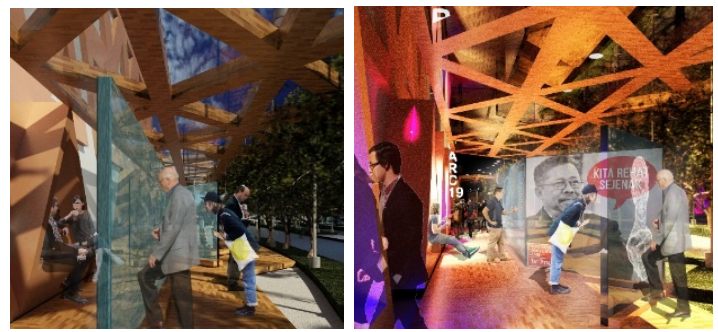

Gambar 33. Intervensi fasad dan hologram Sumber: Dokumentasi Robert, 2019

Untuk mengikat ruang-ruang gathering yang terbentuk dan intervensi kegiatan baru maupun intervensi graphic education, intervensi terakhir dengan menerapkan sebuah garis linear dengan 3 warna utama yaitu merah, hijau dan ungu menjadi guidelines untuk mengarahkan ke titik-titik ruang gathering dan bangunan sekitar sebagai konektivitas di ruang sempadan. (gambar 34).
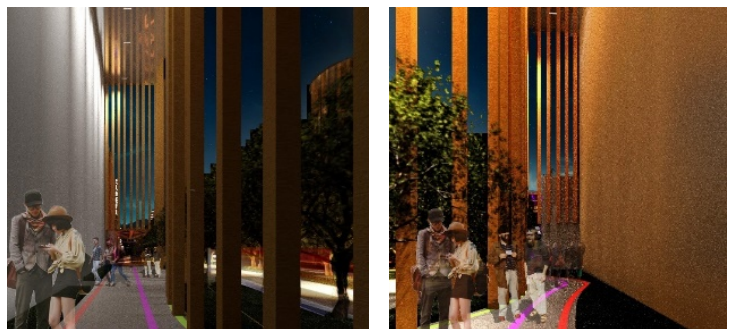

Gambar 34. Intervensi garis linear dengan 3 warna

Sumber: Dokumentasi Robert, 2019

Penerapan 3 warna sebagai konektivitas berdasarkan fungsinya, seperti warna merah merupakan konektivitas yang menghubungkan tempat makan (gathering tempat makan dan restoran/cafe). Selanjutnya untuk warna hijau merupakan konektivitas di sepanjang jalan Taman Kemang yang mengarahkan menuju Transportation Online Hub. Warna ungu merupakan salah satu konektivitas ruangruang gathering untuk beristirahat dan sebagai konektivitas melalui tempat-tempat intervensi kegiatan baru (live movie dan art \& performance) dan intervensi graphic education dan pencahayaan (gambar 35).

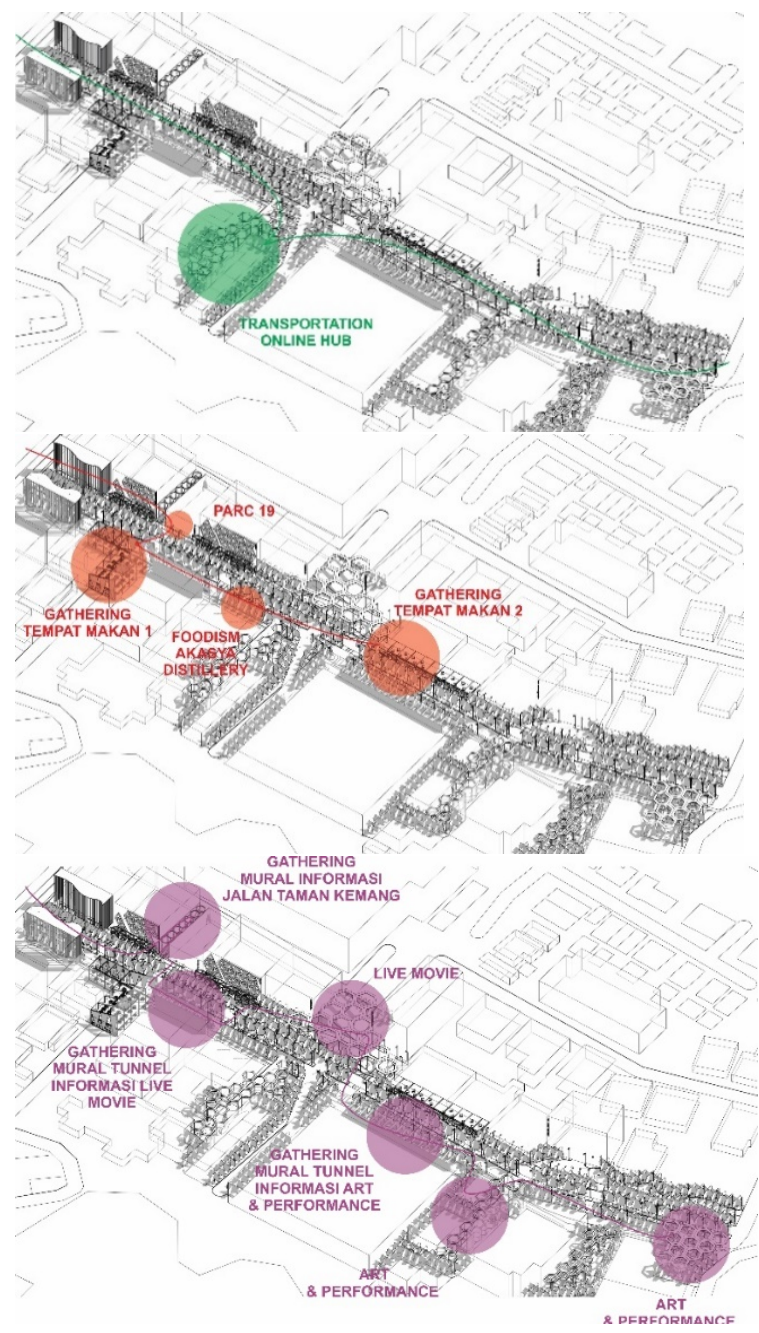

Gambar 35. Diagram konektivitas intervensi garis warna

Sumber: Dokumentasi Robert, 2019

Melalui intervensi kegiatan-kegiatan baru seperti live movie, art \& performance dan graphic education, merupakan salah satu jawaban (solusi) dari kegiatan yang 
monoton melalui aktivitas-aktivitas yang terbentuk di sepanjang jalan, yang bertujuan untuk menghidupkan kembali ruang sempadan di jalan Taman Kemang.

\section{Kesimpulan}

Penelitian ini mencoba menemukan metode untuk membaca keseharian ruang kota melalui pendekatan naratif. Dengan membaca dan menyusun narasi dari ruang jalan Taman Kemang, penulis menemukan suatu konsep dan strategi rancangan yang dapat menghidupkan dan menciptakan keseimbangan aktivitas pada jalan Taman Kemang di sepanjang pagi hingga malam hari. Pendekatan naratif menghasilkan temuan 7 narasi keseharian utama yang digunakan sebagai dasar penyusunan konsep perancangan ruang jalan. Konsep perancangan disusun berdasarkan teori (story - narrative - narration) serta teori karakteristik ruang sempadannya tersebut. Salah satu hasil temuan adalah adanya konsep gathering hingga intervensi kegiatan-kegiatan baru yang memiliki tujuan menghidupkan kembali ruang sempadan.

\section{Ucapan Terima Kasih}

Kami mengucapkan terima kasih kepada Universitas Kristen Duta Wacana yang memberikan kesempatan untuk mempublikasikan pemikiran metode baru dalam menganalisis yaitu pendekatan secara narrative. Serta pihak dari Universitas Pelita Harapan yang memberikan kesempatan dan mendukung penelitian ini.

\section{Daftar Pustaka}

Bain, L., Gray, B., and Rodgers, D. (2012). Living streets : Strategies for crafting public space. Hoboken, NJ: John Wiley \& Sons.

Burlington City Council. (2019). Design guidelines for mixed-use and residential mid-rise buildings. Burlington: Burlington City Council.

Ching, F. D. K. (2015). Architecture: Form, space, and order. Hoboken, NJ: John Wiley \& Sons.

Havik, K. (2014). Urban literacy : Reading and writing architecture. Rotterdam: Nai010 Publishers.

Herman, L. and Vervaeck, B. (2005). Handbook of narrative analysis (Frontiers of narrative). Lincoln, Nebraska: University of Nebraska Press.

Mehta, V. (2009). Look closely and you will see, listen carefully and you will hear: Urban design and social interaction on streets. Journal of Urban Design, Volume 14 (1), 29-64.

Republik Indonesia. (2002). UndangUndang Republik Indonesia Nomor 28 Tahun 2002 tentang bangunan gedung. Jakarta: Lembaran Negara RI. 